\title{
Chromosome Mobilization in Vibrio cholerae (biotype eltor) Mediated by Sex Factor $\mathbf{P}$
}

\author{
By K. BHASKARAN, V. B. SINHA AND S. S. IYER \\ Central Drug Research Institute, Lucknow, India
}

(Received 20 February 1973; revised 7 April 1973)

\begin{abstract}
SUMMARY
Crosses between $\mathrm{P}^{+}$strains of Vibrio cholerae (biotype 'eltor') and $\mathrm{P}^{-}$strains of $V$. cholerae ('classical') were infertile under conditions in which $\mathbf{P}^{+} \times \mathbf{P}^{-}$crosses of $V$. cholerae ('classical') strains were fertile. The efficiency of conjugation, as determined by the frequency of $\mathbf{P}$ transfer, was lower with $\mathrm{P}^{+}$strains of the 'eltor' biotype compared with $\mathrm{P}^{+}$strains of $V$. cholerae ('classical'). However, incubation of $\mathbf{P}^{+}$strains at $44.5{ }^{\circ} \mathbf{C}$, prior to mating, induced fertility in bacteria of the 'eltor' biotype and enhanced it in $V$. cholerae ('classical') crosses. It is suggested that new donors associated with a greater efficiency of conjugation are formed at $44.5{ }^{\circ} \mathrm{C}$ in $\mathrm{P}^{+}$strains of both biotypes.
\end{abstract}

\section{INTRODUCTION}

Genetic recombination in Vibrio cholerae is known to be mediated by a transmissible sex factor P (Bhaskaran, I960, 1964; Bhaskaran \& Sinha, I97I). Crosses between $\mathrm{P}^{+}$and $\mathbf{P}^{-}$strains are fertile and analysis of recombinants showed unidirectional genetic transfer from $\mathrm{P}^{+}$to $\mathrm{P}^{-}$strains (Bhaskaran, 1964 ). The $\mathrm{P}$ factor is also transmissible to strains of $V$. eltor as well as $V$. cholerae ('classical'). The former are distinguished from the latter by their haemolysis $\left(\mathrm{hly}^{+}\right)$of sheep red blood cells (Feeley \& Pittman, 1963), resistance to a Group IV lytic phage (IV-r) (Mukerjee, I963) and to polymyxin (pmx-r) (Gan \& Tjia, 1963) and other traits. $V$. cholerae ('classical') and $V$. eltor are taxonomically indistinguishable because of a wide range of common characters and are now included in the species $V$. cholerae (Hugh, I966). The term 'eltor' is retained here to designate $V$. cholerae strains which are either hly ${ }^{+}$or IV-r because of the observed clear-cut genetic differences between $V$. cholerae ('classical') and strains of the 'eltor' biotype.

In this paper we describe the effects of incubation at $44.5{ }^{\circ} \mathrm{C}$ for $30 \mathrm{~min}$ on $\mathrm{P}^{+}$strains of both biotypes in crosses with $\mathbf{P}^{-}$strains of Vibrio cholerae ('classical'). This temperature, although unfavourable for the growth of Vibrio strains, does not greatly affect viability. Earlier studies at $42{ }^{\circ} \mathrm{C}$, which permitted growth of $V$. cholerae, and at $50{ }^{\circ} \mathrm{C}$, which considerably reduced viability, were ineffective.

\section{METHODS}

Bacterial strains. Of the strains used (Table I), Кв9, Кв 6 and кв46о were derivatives of Vibrio cholerae ('classical') strain 162 (Bhaskaran, I960), whereas KB408 and KB440 were $\mathrm{P}^{+}$derivatives of 'eltor' strains kindly supplied by Dr D. Barua (World Health Organization, Geneva) and Dr A. K. Thomas (Central Research Institute, Kasauli, India) respectively.

Culture media. DNB (Difco Nutrient Broth: Difco Laboratories, Detroit, Michigan, 
Table I. Vibrio cholerae strains

\begin{tabular}{|c|c|c|c|c|c|c|c|c|c|c|c|c|c|}
\hline $\begin{array}{c}\text { Strain } \\
\text { no. }\end{array}$ & $\begin{array}{c}\text { Previous } \\
\text { designation }\end{array}$ & $\begin{array}{l}\text { Sex } \\
\text { factor }\end{array}$ & $i l v$ & arg & his & pur & leu & str & hly & $p m x$ & $\varnothing-I V$ & $\begin{array}{c}\mathrm{O} \text { anti- } \\
\text { genic type }\end{array}$ & Biotype \\
\hline KB 9 & V 58:SR & $\mathrm{P}^{-}$ & - & - & - & + & + & $\mathrm{R}$ & - & S & S & $\mathrm{O}-\mathrm{Og}$ & 'classical' \\
\hline KBI 6 & $\mathrm{~V} 63 \mathrm{P}^{+}$ & $\mathbf{P}^{+}$ & + & + & + & - & - & S & - & $S$ & $S$ & O-In & 'classical' \\
\hline KB460 & - & $\mathrm{P}^{-}$ & - & - & - & + & + & $\mathrm{R}$ & - & S & $\mathbf{S}$ & O-In & 'classical' \\
\hline KB408 & $\mathrm{T} 50 \mathrm{P}^{+}$ & $\mathbf{P}^{+}$ & + & + & + & + & + & $\mathrm{S}$ & - & $\mathbf{R}$ & $\mathrm{R}$ & $\mathrm{O}-\mathrm{Og}$ & 'eltor' \\
\hline KB440 & - & $\mathrm{P}^{+}$ & + & + & + & + & + & S & + & $\mathbf{R}$ & $\mathrm{R}$ & $\mathrm{O}-\mathrm{Og}$ & 'eltor' \\
\hline
\end{tabular}

Abbreviations: ilv, isoleucine + valine; arg, arginine; his, histidine; pur, purines; leu, leucine; str, streptomycin; $h l y$, haemolytic activity; $p m x$, polymyxin; $\varnothing-I V$, Group IV lytic phage; O-Og, O antigenic type Ogawa; $\mathrm{O}-\mathrm{In}, \mathrm{O}$ antigenic type Inaba.

- = absence sex factor or haemolytic activity or nutritional requirement. $\mathrm{R}$ and $\mathrm{S}=$ resistance or sensitivity.

U.S.A.) was prepared by dissolving $16 \mathrm{~g}$ in $1000 \mathrm{ml}$ of a $0.5 \%$ solution of $\mathrm{NaCl}$ and $\mathrm{BHI}$ (Brain Heart Infusion: Difco Laboratories) by dissolving $37 \mathrm{~g}$ in $1000 \mathrm{ml}$ of distilled water. Semisolid (sloppy) and solid media contained respectively 0.4 and $\mathrm{I} \cdot 0 \%$ agar (Oxoid, no. 3 ). The minimal medium was that of Bhaskaran \& Sinha (I97I). All media were sterilized at I $5 \mathrm{lb} / \mathrm{in}^{2}$ for $10 \mathrm{~min}$.

Crosses. Crosses were performed as described earlier (Bhaskaran \& Sinha, I97I) except that, when required, subcultures were incubated for a further $30 \mathrm{~min}$ at $44.5{ }^{\circ} \mathrm{C}$.

To determine the persistence of the $44.5{ }^{\circ} \mathrm{C}$ temperature effect on $\mathrm{P}^{+}$strains, $0.5 \mathrm{ml}$ amounts were transferred to $9.5 \mathrm{ml}$ fresh $\mathrm{BHI}$ and incubated at $37{ }^{\circ} \mathrm{C}$. Viable counts were made at 30 min intervals and samples taken for crosses with appropriate $\mathrm{P}^{-}$strains. In these crosses, as in controls, $10^{8}$ to $10^{9}$ donor $\left(\mathrm{P}^{+}\right)$organisms were mixed with about $10^{10}$ organisms of the recipient $\left(\mathrm{P}^{-}\right)$and the suspensions passed through membrane filters ('Metricel', Gelman Instrument Co., Ann Arbor, Michigan, U.S.A.; pore size, $0.2 \mu \mathrm{m}$ ). These filters were placed on the surface of BHI agar plates and incubated at $37^{\circ} \mathrm{C}$ for $60 \mathrm{~min}$. Mated organisms were then suspended in minimal medium and streaked on selective minimal agar for the isolation of recombinants. In this study, the donor selective marker was either $i l v^{+}$ or $\mathrm{arg}^{+}$with str-r as the recipient selective marker.

Test for $P$ factor. For gross differentiation of $\mathrm{P}^{+}$and $\mathrm{P}^{-}$strains, cross-matching tests were performed in semisolid agar (Bhaskaran \& Sinha, I 97I). $\mathrm{P}^{+}$strains showed a growth-thinning effect on indicator $\mathrm{P}^{-}$strains but not on $\mathrm{P}^{+}$strains. $\mathrm{P}^{-}$strains had no effect on either strain.

For the assay of $\mathrm{P}^{+}$bacteria (Bhaskaran, 1964), $0.5 \mathrm{ml}$ of tenfold dilutions of the test culture were mixed with $0.2 \mathrm{ml}$ of a $3 \mathrm{~h} \mathrm{BHI} \mathrm{culture} \mathrm{of} \mathrm{KB9}\left(\mathrm{P}^{-}\right)$in $7 \mathrm{ml}$ of soft agar (DNB) on the surface of DNB agar plates. When the soft agar had set, the plates were inverted and incubated overnight at $37^{\circ} \mathrm{C}$. The number of $\mathrm{P}^{+}$organisms was correlated with the number of clearings (infectious centres) observed.

This procedure was modified when the efficiency of conjugation (as indicated by transfer of $\mathbf{P}$ factor) between $\mathrm{P}^{+}$and $\mathrm{P}^{-}$strains of Vibrio cholerae was determined. Streptomycinsensitive $\mathbf{P}^{+}$and streptomycin-resistant $\mathbf{P}^{-}$organisms were mated on membranes and the numbers of newly infected $\mathrm{P}^{+}$organisms assayed after 30 min contact. For this purpose the organisms were suspended in DNB and assayed for $\mathrm{P}^{+}$cells as described above using the parental $\mathrm{P}^{-}$strain as indicator. In these tests, the soft overlay as well as the basal DNB agar contained streptomycin sulphate $(500 \mu \mathrm{g} / \mathrm{ml})$ to inhibit further spread of $\mathbf{P}$ factor from parental $\mathrm{P}^{+}$to indicator $\mathrm{P}^{-}$strain during the overnight incubation required for the development of discrete clearings (infectious centres). The same $\mathrm{P}^{+}$and $\mathrm{P}^{-}$strains were used in control experiments but without mating on membranes. 
Table 2. Genetic transfer from $P^{+}$strains of Vibrio cholerae (biotype 'eltor') to $P^{-}$strain $\mathrm{KB} 460$ of $V$. cholerae ('classical'); effect of incubation of the donor strain at $44.5{ }^{\circ} \mathrm{C}$ for $30 \mathrm{~min}$

\begin{tabular}{|c|c|c|c|c|c|c|c|c|}
\hline \multirow[b]{2}{*}{ Strain } & & \multirow{2}{*}{$\begin{array}{l}3 \text { h BHI } \\
\text { culture } \\
\text { at } 37^{\circ} \mathrm{C} \\
\text { (control) }\end{array}$} & \multicolumn{6}{|c|}{$\begin{array}{c}\text { Time of incubation }\left(\mathrm{min} \text { ) at } 37^{\circ} \mathrm{C} \text { after }\right. \\
\text { keeping for } 30 \mathrm{~min} \text { at } 44.5^{\circ} \mathrm{C}\end{array}$} \\
\hline & & & 0 & 30 & 60 & 90 & 120 & 150 \\
\hline \multirow[t]{3}{*}{$\begin{array}{r}\text { KB440 P+ } \\
\text { ('eltor') }\end{array}$} & $\begin{array}{l}\text { Viable count } / \mathrm{ml} \\
\text { No. of generations } \\
\text { No. of recombinants } \\
10^{8} \text { donor bacteria }\end{array}$ & $9.00 \times 10^{8}$ & $\begin{array}{c}3.60 \times 10^{7} \\
-\end{array}$ & $\begin{array}{c}4.00 \times 10^{7} \\
0.15\end{array}$ & $\begin{array}{c}8 \cdot 90 \times 10^{7} \\
1 \cdot 31\end{array}$ & $\begin{array}{c}3.60 \times 10^{8} \\
3.32\end{array}$ & $\begin{array}{c}6.40 \times 10^{8} \\
4.15\end{array}$ & $\begin{array}{c}\mathrm{I} \cdot 08 \times 10^{9} \\
4.9 \mathrm{I}\end{array}$ \\
\hline & $\arg ^{+}$str-r & Nil & 108 & 9I 3 & $39 \mathrm{I}$ & 43 & 9 & 4 \\
\hline & $i l v^{+} s t r-r$ & Nil & 135 & I I 58 & 395 & 34 & 13 & 7 \\
\hline \multirow[t]{4}{*}{$\begin{array}{r}\text { KB408 } \mathrm{P}^{+} \\
\text {('eltor') }\end{array}$} & $\begin{array}{l}\text { Viable count } / \mathrm{ml} \\
\text { No. of generations }\end{array}$ & $\begin{array}{l}8.38 \times 10^{8} \\
-\end{array}$ & $\begin{array}{c}2 \cdot 20 \times 10^{7} \\
-\end{array}$ & $\begin{array}{l}3 \cdot 10 \times 10^{7} \\
0.50\end{array}$ & $\begin{array}{c}5 \cdot 20 \times 10^{7} \\
1 \cdot 24\end{array}$ & $\begin{array}{c}7 \cdot 20 \times 10^{7} \\
I \cdot 71\end{array}$ & $\begin{array}{c}1.84 \times 10^{8} \\
3.06\end{array}$ & $\begin{array}{c}5.30 \times 10^{8} \\
4.61\end{array}$ \\
\hline & $\begin{array}{l}\text { No. of recombinants } \\
10^{8} \text { donor bacteria }\end{array}$ & & & & & & & \\
\hline & $\arg ^{+}$str-r & 7 & $32 \mathrm{I}$ & 1021 & 1852 & $86 \mathrm{I}$ & 122 & 26 \\
\hline & $i l v^{+} s t r-r$ & 2 & I39 & 1037 & I 590 & 814 & 165 & 58 \\
\hline
\end{tabular}

RESULTS

Crosses between $P^{+}$strains of Vibrio eltor and $P^{-}$strains of 'classical' biotype. No recombinants were obtained when KB440 ('eltor', $\mathrm{P}^{+}$) was mated with KB460 ('classical', $\mathrm{P}^{-}$) when both strains were grown at $37^{\circ} \mathrm{C}$ prior to mating (Table 2). Following incubation of the donor strain at $44.5{ }^{\circ} \mathrm{C}$ for $30 \mathrm{~min}$, there was an immediate appearance of fertility which reached its peak 30 min after subsequent incubation at $37^{\circ} \mathrm{C}$ and then declined rapidly until after 150 min the cross was practically infertile. As the mating took place on a membrane during incubation at $37^{\circ} \mathrm{C}$ for $60 \mathrm{~min}$, the period of maximal fertility is likely to be between 30 and 90 min after incubation at $44.5{ }^{\circ} \mathrm{C}$. This would correspond to about three generations on the assumption that the growth of $\mathrm{P}^{+}$bacteria on the membrane was similar to that in BHI. However, this might not be the case because $\mathrm{F}^{+}$strains of Escherichia coli stopped multiplying when mixed in $\mathrm{I}$ : Io ratio with $\mathrm{F}^{-}$bacteria (Evenchik, Stacey \& Hayes, 1969). Recombinant frequencies with samples taken after 60 min (when the population had just doubled) showed a sharp decline; thus it is clear that the donor state was fully expressed before the first cell division but not later. The donor state was therefore not heritable. This finding is in fact very similar to ultraviolet induction of chromosome transfer in $E$. coli (Evenchik et al. 1969) where the induced donor state can be attributed to the formation of a genetic structure which can lead to transfer but cannot replicate.

Crosses between another 'eltor' $\mathrm{P}^{+}$strain, Кв 408 and the same $\mathrm{P}^{-}$strain ('classical'), KB460, gave similar results (Table 2). In this case, maximal fertility was seen at 60 min after incubation at $44.5{ }^{\circ} \mathrm{C}$ (after one generation) but decline commenced before the end of the second generation. A low degree of residual fertility was retained after I 50 min (4.6I generations). The few colonies which appeared in controls were probably revertants of the $\mathrm{P}^{-}$ strain.

These observations were confirmed in three repetitions of each of the above two crosses and on no occasion did maximum fertility extend beyond $60 \mathrm{~min}$ after incubation at $44.5{ }^{\circ} \mathrm{C}$. To facilitate interpretation of these findings, the effect of incubating the donor at $44.5{ }^{\circ} \mathrm{C}$ in crosses between $\mathrm{P}^{+}$and $\mathrm{P}^{-}$strains of 'classical' Vibrio cholerae, of known fertility, was 
Table 3. Genetic transfer from $P^{+}$strain $\mathrm{KB} \mathrm{I} 6$ of Vibrio cholerae ('classical'), to $P^{-}$- strain $\mathrm{KB} 460$ of $V$. cholerae ('classical'); effect of incubation of the donor strain at $44.5{ }^{\circ} \mathrm{C}$ for $30 \mathrm{~min}$

\begin{tabular}{|c|c|c|c|c|c|c|c|}
\hline & \multirow{2}{*}{$\begin{array}{l}3 \mathrm{~h} \mathrm{BHI} \\
\text { culture } \\
\text { at } 37^{\circ} \mathrm{C} \\
\text { (control) }\end{array}$} & \multicolumn{6}{|c|}{ Time of incubation (min.) at $37^{\circ} \mathrm{C}$ after 30 min at $44.5^{\circ} \mathrm{C}$} \\
\hline & & o & 30 & 60 & 90 & 120 & 150 \\
\hline Viable count/ml & $5 \cdot 90 \times 10^{8}$ & $2.80 \times 10^{7}$ & $3.20 \times 10^{7}$ & $5.80 \times 10^{7}$ & $1.55 \times 10^{8}$ & $3.20 \times 10^{8}$ & $4.40 \times 10^{8}$ \\
\hline No. of generations & - & - & 0.19 & $1 \cdot 05$ & $2 \cdot 47$ & $3 \cdot 52$ & 3.97 \\
\hline \multicolumn{8}{|l|}{$\begin{array}{l}\text { No. of recombinants/ } \\
10^{8} \text { donor bacteria }\end{array}$} \\
\hline $\arg ^{+}$str-r & 176 & 778 & 2796 & 3469 & 945 & $54 \mathrm{I}$ & 418 \\
\hline$i l v^{+} s t r-r$ & 197 & $107 \mathrm{I}$ & 2572 & 2545 & 804 & 419 & 527 \\
\hline
\end{tabular}

Table 4. Efficiency of $P$ transfer to $P^{-}$strain $\mathrm{KB9}$ of Vibrio cholera ('classical') in crosses; effect of incubation of donor strains at $44 \cdot 5^{\circ} \mathrm{C}$ for $30 \mathrm{~min}$

\begin{tabular}{cccc} 
& Donor incubation & \multicolumn{2}{c}{ Efficiency of P transfer* } \\
temperature & Expt I & Expt 2 \\
KBI6 ('classical') & $4{ }^{\circ} \mathrm{C}$ (control) & $200 \cdot 6$ & $1 \mathrm{I} 9 \cdot 6$ \\
& $44.5{ }^{\circ} \mathrm{C}$ & $428 \cdot \mathrm{I}$ & 164.4 \\
KB 408 ('eltor') & $4{ }^{\circ} \mathrm{C}$ (control) & $17 \cdot 2$ & $12 \cdot 3$ \\
& $44.5{ }^{\circ} \mathrm{C}$ & 34.8 & $17 \cdot 5$ \\
KB 440 ('eltor') & $4{ }^{\circ} \mathrm{C}$ (control) & $30 \cdot 5$ & 23.0 \\
& $44.5{ }^{\circ} \mathrm{C}$ & $83 . \mathrm{I}$ & 92.8
\end{tabular}

* The efficiency of $\mathbf{P}$ transfer was calculated as the no. of clearings (infectious centres)/Ioo viable donor organisms.

studied. Recombination frequencies were higher immediately after incubation of the $\mathbf{P}^{+}$ strain at $44.5{ }^{\circ} \mathrm{C}$ with a maximum at the time of the first cell division (Table 3 ). This means that even in cultures containing competent donors, their relative numbers were increased after incubation at $44.5{ }^{\circ} \mathrm{C}$. This is in contrast to 'eltor' $\mathrm{P}^{+}$strains in which such competent donors only appeared after incubation at $44.5{ }^{\circ} \mathrm{C}$.

A possible explanation for the induced donor activity in 'eltor' $P^{+}$strains incubated at $44.5{ }^{\circ} \mathrm{C}$. There could be two explanations for the failure of 'eltor' $\mathrm{P}^{+}$strains grown at $37^{\circ} \mathrm{C}$ to yield recombinants: conjugation between 'eltor' $\mathbf{P}^{+}$and 'classical' $\mathbf{P}^{-}$strains did not occur to any significant extent and/or chromosomal transfer did not take place. As the $\mathbf{P}$ factor is transmissible by conjugation, the frequency of its transfer should indicate the efficiency of conjugation. This was determined in crosses between three streptomycinsensitive $\mathrm{P}^{+}$strains and a streptomycin-resistant $\mathrm{P}^{-}$strain on membrane filters. To permit every $\mathrm{P}^{+}$cell to conjugate with at least one $\mathrm{P}^{-}$cell, $\mathrm{P}^{+}$and $\mathrm{P}^{-}$bacteria were mated in the ratio of $\mathrm{I}: \mathrm{ro}$.

Conjugation between Vibrio cholerae ('classical') strains was highly efficient and P transfer was in excess of $100 \%$ after 30 min contact on the membrane (Table 4 ). Incubation at $44.5^{\circ} \mathrm{C}$ for $30 \mathrm{~min}$ (and subsequent incubation at $37^{\circ} \mathrm{C}$ for $60 \mathrm{~min}$ ) gave even higher values. With 'eltor' $\mathrm{P}^{+}$strains conjugation was less efficient; incubation of $\mathrm{KB} 408$ at $44.5^{\circ} \mathrm{C}$ effected a slight increase whereas with strain $\mathrm{KB} 440$ the effect was greater, approaching $100 \%$. In control experiments with the same suspensions of streptomycin-sensitive $\mathrm{P}^{+}$and 
Table 5. Frequency of transfer of $P$ factor to $P^{-}$strain $\mathrm{KB9}$ of Vibrio cholerae ('classical') in soft agar containing streptomycin lethal to the donor $\left(P^{+}\right)$strains

\begin{tabular}{|c|c|c|c|c|}
\hline $\mathrm{P}+$ strain & $\begin{array}{c}\text { Expt } \\
\text { no. }\end{array}$ & $\begin{array}{l}\text { Viable count of } \\
\mathbf{P}^{+} \text {bacteria } / \mathrm{ml}\end{array}$ & $\begin{array}{l}\text { No. of infectious } \\
\text { centres } / \mathrm{ml}\end{array}$ & $\begin{array}{l}\% \text { frequency } \\
\text { of P transfer }\end{array}$ \\
\hline KB 408 ('eltor')* & $\begin{array}{l}1 \\
2\end{array}$ & $\begin{array}{l}1.24 \times 10^{8} \\
1.07 \times 10^{8}\end{array}$ & $\begin{array}{l}3.60 \times 10^{5} \\
4.90 \times 10^{5}\end{array}$ & $\begin{array}{l}0.29 \\
0.46\end{array}$ \\
\hline KB 440 ('eltor')* & $\begin{array}{l}\text { I } \\
2\end{array}$ & $\begin{array}{l}\mathrm{I} .59 \times 10^{8} \\
\mathrm{I} .63 \times 10^{8}\end{array}$ & $\begin{array}{l}5.30 \times 10^{5} \\
1.50 \times 10^{6}\end{array}$ & $\begin{array}{l}0.33 \\
0.92\end{array}$ \\
\hline Кв I6 ('classical') & I & $1 \cdot 32 \times 10^{8}$ & $7 \cdot 20 \times 10^{5}$ & 0.55 \\
\hline KB I 6 ('classical')* & I & $1 \cdot 17 \times 10^{8}$ & $\mathrm{I} \cdot 43 \times 1 \mathrm{IO}^{6}$ & $I \cdot 22$ \\
\hline
\end{tabular}

streptomycin-resistant $\mathrm{P}^{-}$strains without mating on a membrane, $\mathrm{P}$ transfer was low $(0 \cdot 29$ to $1 \cdot 22 \%$; Table 5) in the presence of streptomycin. This confirmed that the frequencies shown in Table 4 reflect the efficiency of $\mathbf{P}$ transfer by conjugation.

The $\mathrm{P}$ transfer in excess of $100 \%$ observed with 'classical' Vibrio cholerae кв 6 could have resulted from either a further spread of $\mathbf{P}$ factor from newly infected $\mathbf{P}^{+}$bacteria or multiple rounds of conjugation between a $\mathbf{P}^{+}$bacterium and several $\mathbf{P}^{-}$bacteria. On the other hand, multiplication of parental and newly infected $\mathrm{P}^{+}$organisms could have been involved. Furthermore, 'eltor' $\mathrm{P}^{+}$strains were not totally deficient in conjugational ability. Although frequency of conjugation was less than with 'classical' $\mathrm{P}^{+}$strains ( 12.3 to $30.5 \%$ ), conjugation did occur in the two strains studied even without incubation at $44.5{ }^{\circ} \mathrm{C}$.

\section{DISCUSSION}

Genetic recombination between two strains of Vibrio cholerae ('eltor' biotype) and a strain of $V$. cholerae ('classical') showed certain interesting features which distinguished them from crosses between two $V$. cholerae ('classical') strains. The $\mathrm{P}^{+}$'eltor' strains were inefficient as gene donors to a $\mathrm{P}^{-}$'classical' $V$. cholerae strain under normal conditions of mating but incubation of the former at $44.5{ }^{\circ} \mathrm{C}$ induced transient increased levels of fertility (Table 2). 'Classical' $\mathbf{P}^{+}$strains were generally fertile in crosses with $\mathbf{P}^{-}$strains of $V$. cholerae ('classical') but recombination frequencies increased after incubation of the donor strain at $44.5{ }^{\circ} \mathrm{C}$ (Table 3). No appreciable differences were observed by incubating recipient $\mathbf{P}^{-}$strains at $44.5{ }^{\circ} \mathrm{C}$. Reverse crosses, i.e. mating $\mathrm{P}^{-}$'eltor' with $\mathrm{P}^{+}$'classical' $V$. cholerae, seem to be fertile without incubation of either strain at $44.5^{\circ} \mathrm{C}$. All $\mathrm{P}^{-} \times \mathrm{P}^{-}$crosses were infertile and unaffected by incubation at $44 \cdot 5{ }^{\circ} \mathrm{C}$.

Efficiency of conjugation as indicated by frequency of $\mathrm{P}$ transfer was greater when both $\mathrm{P}^{+}$and $\mathrm{P}^{-}$strains were of the 'classical' biotype than between 'eltor', $\mathrm{P}^{+}$and 'classical' $\mathrm{P}^{-}$ strains (Table 4). Had this been the only reason for the difference in fertility between'the two crosses, one would expect reduction in recombination frequency but not its absence. Incubation at $44.5{ }^{\circ} \mathrm{C}$ did enhance efficiency of conjugation three to fourfold but this cannot account for the considerable increase of gene donor activity in 'eltor' strains. Some form of chromosomal mobilization appears to occur in these strains at $44.5{ }^{\circ} \mathrm{C}$. It may be that DNA strand breaks occur at $44.5{ }^{\circ} \mathrm{C}$ (Bridges, Ashwood-Smith \& Munson, 1969) resulting in a transient association between the sex factor $\mathrm{P}$ and bacterial chromosomal segments in 'eltor' strains. Such events probably occurred normally in 'classical' Vibrio cholerae strains even at $37^{\circ} \mathrm{C}$. As proposed for Escherichia coli (Evenchik et al. 1969) such transient 
structures may be transferred by conjugation from bacterium to bacterium leading to genetic recombination.

Analysis of unselected markers in the recombinants isolated has been unsatisfactory because of the low incidence of linkage in Vibrio cholerae (Bhaskaran, 1964). Thus linkage differences between the induced donor state at $44.5{ }^{\circ} \mathrm{C}$ and in normal donors at $37{ }^{\circ} \mathrm{C}$ in $\mathbf{P}^{+}$strains of 'classical' $V$. cholerae cannot be detected.

Dr K. Bhaskaran is grateful to the World Health Organization for financial support of this study. This paper is communication no. I834 of the Central Drug Research Institute.

\section{REFERENCES}

BHASKARAN, K. (1960). Recombination of characters between mutant stocks of Vibrio cholerae, strain 162. Journal of General Microbiology 23, 47-54.

BhASKARAN, K. (1964). Segregation of genetic factors during recombination in Vibrio cholerae, strain 162. Bulletin of the World Health Organization 30, 845-853.

BHASKARAN, K. \& SINHA, V. B. (I97I). Transmissible plasmid factors and fertility inhibition in Vibrio cholerae. Journal of General Microbiology 69, 89-97.

Bridges, B. A., Ashwood-Smith, M. J. \& Munson, R. J. (1969). Correlation of bacterial sensitivities to ionizing radiation and mild heating. Journal of General Microbiology 58, I I 5-I 24.

EvenchiK, Z., StAceY, K. A. \& Hayes, W. (1969). Ultraviolet induction of chromosome transfer by autonomous sex factors in Escherichia coli. Journal of General Microbiology 56, I-I4.

Feeley, J. C. \& Pittman, M. (1963). Studies on the haemolytic activity of El Tor vibrios. Bulletin of the World Health Organization 28, 347-356.

GAN, K. H. \& TJIA, S. K. (1963). A new method for differentiation of Vibrio comma and Vibrio el tor. American Journal of Hygiene 77, $184-186$.

Hugh, R. (1966). A comparison of the neotype strain and I 19 isolates of Vibrio el Tor Pribram I933. Indian Journal of Medical Research 54, 839-848.

MUKERJEe, S. (1963). The bacteriophage-susceptibility tests in differentiating Vibrio cholerae and Vibrio el tor. Bulletin of the World Health Organization 28, 333-336. 